\title{
PENGARUH KUALITAS PELAYANAN TRANSPORTASI UMUMBUS TRANS JOGJA TERHADAP KEPUASAN KONSUMEN
}

\author{
Arif Wibowo, MEI \\ Email: arif_wibowo@uny.ac.id \\ Jurusan Manajemen Fakultas Ekonomi, Universitas Negeri Yogyakarta
}

\begin{abstract}
This research was conducted to examine the effect of Level of Service Quality Public Transport Bus Trans Jogja to customer satisfaction. Trans Jogja bus this is an attempt Yogyakarta Provincial Government since 2008 with the aim to improve public services, especially in the land transport sector in urban areas based DIY to replace the deposit system into a system service purchase. A very important factor in consumer satisfaction is service quality, which is measured in the quality aspects of the service will be a service is satisfied or not satisfied user when using these services so that these aspects can be seen whether the quality of services provided is good or not good. The quality of transport good services and should attention wants and needs of consumers. Every customer have a perspective different to all forms of transportation layananpada. Whether or not consumers are satisfied with the product will affect the service behavior shown next.

The sample used in this study is 100 respondents. The sampling method using purposive sampling. The result show that by using regression ( $\mathrm{R}$ square) methods, it can be concluded that tangible of variable positive and significant impact on consumer satisfaction with a significance value ( $\mathrm{P}$ Value) of $0.308<0.05$. While the reliability of a positive and significant effect on customer satisfaction with a significance value (P Value) of $0.305>0.05$. Assurance significant positive effect on customer satisfaction with a significance value (P Value) of $0.194<0.05$. Responsiveness positive and significant impact on consumer satisfaction with a significance value ( $\mathrm{P}$ Value) of $0.301>0.05$. For empathy and a significant positive effect on consumer satisfaction with a significance value (P Value) of 0.259>0.05.

Keywords: Tangible, Reliability, Assurance, Responsiveness, Empathy, Customer Satisfaction

\section{Latar Belakang Masalah}

Alat transportasi umumnya memliki tujan untuk memperlancar kegiatan masyarakat untuk beraktivitas. Sedangkan alat transportasi itu dibedakan

menjadi tiga yaitu alat transportasi darat, alat transportasi laut, alat transportasi udara. Setiap perusahaan berusaha memberikan pelayanan yang terbaik dengan fasilitas yang memadai bagi
\end{abstract}


konsumennya agar mereka puas terhadap jasa yang mereka rasakan dan mereka maumenjadi pelanggan.Kualitas pelayanan juga memiliki hubungan yang erat dengan kepuasan pelanggan.Kualitas memberikan nilai tersendiri di mata konsumen untuk menjalin hubungan yang kuat antara pengguna jasa dengan perusahaan.

Strategi untuk jangka panjangnya memungkinkan perusahaan untuk bisa memahami harapan pelanggan serta kebutuhan yang mereka inginkan.Alat transportasi umum yang ada di Yogyakarta terdiri dari alat transportasiyang dapat mengangkut banyak orang seperti bus. Pada awalnya jumlah bus di Yogyakarta sangatlah banyak, namun pada perkembangan selanjutnya bus sudah menjadi alat transportasi bagi semua lapisan masyarakat lapisan bawah, menengah dan atas. Akhirnya pemerintah Yogyakarta mengadakan bus Trans Jogja yang bakal mencukupi kebutuhan masyarakat Yogyakarta akan adanya bus yang nyaman dan terjangkau.

Bus Trans Jogja merupakan salah satu alat transportasi umum sejak tahun 2008 yang hadir untuk memenuhi kebutuhan masyarakat, dengan melihat semakin meningkatnya aktivitas masyarakat di wilayah Yogyakarta seperti para mahasiswa yang memilih berpergian menggunakan bus atau keluarga yang hanya sekedar jalan-jalan.Bus Trans Jogja ini adalah sebuah upaya Pemerintah Provinsi DIY untuk meningkatkan pelayanan publik khususnya pada sektor transportasi darat di kawasan perkotaan DIY dengan berbasis menggantikan sistem setoran menjadi sistem pembelian pelayanan. Faktor yang sangat penting dalam kepuasan konsumen adalah kualitas pelayanan, aspek yang diukur dalam kualitas pelayanan akan suatu jasa adalah puas atau tidak puasnya pengguna ketika menggunakan jasa tersebut sehingga dari aspek tersebut dapat terlihat apakah kualitas pelayanan yang diberikan sudah baik atau belum baik. Kualitas pelayanan jasa transportasi yang baik seharusnya memperhatikan keinginan dan kebutuhan dari konsumen. Setiap konsumen memiliki cara pandang yang berbeda-beda terhadap segala bentuk layananpada jasa transportasi. Puas atau tidaknya konsumen dengan produk layanan akan mempengaruhi tingkah laku yang ditampilkan berikutnya.

Menurut Tjiptono (2007), terdapat lima kelompok karakteristik yang digunakan oleh konsumen dalam mengevaluasi ataupun menilai suatu kualitas pelayanan jasa yaitu sebagai berikut: keandalan (realibility) adalah kemampuan untuk memberikan pelayanan yang sesuaidengan fungsi yang ditawarkan, ketanggapan atau daya 
tanggap (responsivenes)adalah kesigapan karyawan dalam membantu konsumen dan memberikan pelayanan informasi dengan cepat, jaminan (assurance) adalah untuk mengukur kemampuan dan kesopanan karyawan serta sifat yang dapat dipercaya yang dimiliki oleh karyawan, bukti langsung (tangibles) yang meliputi penampilan fisik, kebersihan dan kerapian karyawan serta kelengkapan komunikasi, Empathy adalah tatacara yang digunakan penyelenggara pelayanan untuk menunjukkan rasa peduli dan perhatian kepada konsumen. Selain melihat faktor kualitas pelayanan, kepuasan konsumen juga melihatdari sisi harga, istilah harga dapat diartikan sebagai jumlah uang (satuan moneter) dan /atau aspek lain (nonmoneter) yang mengandung utilitas atau kegunaan tertentuyang diperlukan untuk mendapatkan suatu jasa (Tjiptono 2007). Lupiyoadi (2006) bahwa manfaat yang dimiliki oleh suatu produk jasa harus dibandingkan dengan berbagai biaya (pengorbanan) yang ditimbulkan dalam mengkonsumsi layanan jasa tersebut. Adanya kesesuaian antara harga dan kualitas produk atau jasa dapat membuat kepuasan bagi konsumen. Biasanya konsumen dalam menggunakan layanan jasa akan membandingbandingkan harga, memilih layanan jasa yang harga dasarnya murah, memilih layanan jasa yang harganya sebanding dengan kualitasnya atau berbagai alasan lainnya.

Secara umum, kepuasan adalah perasaan senang atau kecewa seseorang yangberasal dari perbandingan antara kesan terhadap hasil suatu produk dengan harapan harapannya (Kotler, 2009). Tjiptono (2004) mendefinisikan kepuasan konsumen atau pelanggan sebagai evaluasi secara sadar atau penilaian kognitif menyangkut apakah kinerja produk relatif bagus atau jelek apakah produk bersangkutan cocok atau tidakcocok dengan tujuan atau pemakaiannya. Kepuasan konsumen merupakan salah satu faktor penentu dari keberhasilan pengusaha, maka harus memperhatikan antaraharapan yang diinginkan oleh masyarakat dengan jasa yang diberikan. Artikel ini bertujuan untuk menguji pengaruh kualitas pelayanan terhadap kepuasan konsumen transportasi umum bus trasn Jogja.

\section{Pengertian Pemasaran}

Pemasaran merupakan sebuah faktor penting dalam suatu siklus yang bermula dan berakhir dalam kebutuhan konsumen. Suatu siklus akan berakhir apabila konsumen merasa puas terhadap pemilikan suatu barang atau jasa. Siklus ini akan terjadi secara berulang-ulang atau terus-menerus. Kegiatan pemasaran harus dapat memberikan kepuasan kepada konsumen jika menginginkan 
usahanya berjalan terus menerus atau konsumen mempunyai pandangan yang baik terhadap perusahaannya. Menurut Philip Kotler (1997) pemasaran adalah suatu proses sosial dan manajerial yang didalamnya individu dan kelompok mendapatkan apa yang mereka butuhkan dan inginkan dengan menciptakan,menawarkan dan mempertukarkan produk yang bernialai dengan pihak lain. Pemasaran adalah suatu kegiatan usaha yang mengarahkan aliran barang dan jasa dari produksen kepada konsumen atau pemakai. (Basu Swasta, 1984).

Berdasarkan penjelasan tentang definisi pemasaran diatas, menunjukkan bahwa pemasaran merupakan penjelasan tentang definisi kegiatan yang bersifat integral. Dimana pemasaran bukan hanya sekedar suatu cara sederhana untuk memaksimalkan target dari kegiatan penjualan (karena penjualan hanya merupakan suatu tahap dari proses pemasaran), melainkan pemasaran juga dilakukan sebelum maupun sesudah kegiatan penjualan.

\section{Pengertian jasa}

Setiap kegiatan atau manfaat yang ditawarkan oleh suatu pihak pada pihak lain dan pada dasarnya tidak terwujud, serta tidak menghasilkan kepemilikan sesuatu" (Kotler, 1994). Berdasarkan definisi diatas dapat diambil kesimpulan bahwa jasa atau pelayanan merupakan suatu kinerja yang tidak berwujud dan cepat hilang, tetapi tidak dirasakan daripada dimiliki, dimana pelanggan lebih dapat berpartisipasi aktif dalam proses mengkonsumsi jasa tersebut. Namun kondisi cepat atau lambatnya pertumbuhan jasa sangat tergantung pada penilaian pelanggan terhadap kinerja atau penampilan yang ditawarkan oleh pihak produsen (perusahaan barang atau jasa). Menurut Fandy Tjipto (1995), jasa mempunyai 4 karakteristik yaitu Intengibility, Inseparability, Variability, dan Perishability.

Intengibility (tidak dapat dilihat, dirasakan). Jasa bersifat intengibilityartinya jasa tidak dapat dilihat, dirasa, diraba, dicium atau didengar sebelum pelanggan mencoba atau membeli. Karena sifat jasa ini tidak dapat disentuh dan tidak dapat dirasa dan sesuatu yang tidak mudah didefinisikan, diinformasikan atau dipahami secara rohani. Maka dalam hal ini perusahaan jasa menghadapitantangan untuk memberikan bukti-bukti fisik dan perbandingan pada penawaran abstraknya. Inseparability (tidak dapat dipisahkan) Jasa pada dasarnya tidak dapat dipisahkan dari penyedia. Hal ini bisa dilihat dari faktor-faktor pendukung yang tidak kalah pentingnya dalam pemberian perhatian khususnya pada 
tingkat partisipasi atau keterlibatan pelanggan dalam proses jasa misalnya aktivitas dan peran serta pelajar atau mahasiswa dalam pendidikan disekolah maupun di perguruan tinggi. Variability(keragaman) Jasa bersifat sangat variabel karena merupakan non standardized out-put artinya banyak variasi bentuk, kualitas dan jenis tergantung padasiapa, kapan, dan dimana jasa tersebut dihasilkan. Dalam hal ini penyedia jasa dapat menggunakan 3 pendekatan dalam pengendalian kualitas jasa yaitu: Melakukan investasi dalam seleksi dan pelatihan personalia yang baik,melakukan standarisasi proses pelaksanan jasa. Dalam hal ini dapat dilakukan dalam diagram jalur dengan tujuan untuk mengetahui faktor-faktor potensial yang dapat menyebabkan kegagalan dalam jasa, dan memantau kepuasan pelanggan melalui sistem sarana dan keluhan survey pelanggan sehingga pelayanan yang kurang baik dapat dideteksi dan dikoreksi. Perishability(tidak tahan lama). Jasa merupakan komoditas tidak tahan lamadan tidak dapat disimpan dan jasa sangat bervariasi dalam melakukan pemasaran jasa yang di pengaruhi faktor musiman. Kualitas memiliki hubungan yang erat dengan kepuasan konsumen kualitas dalam organisasi jasa tertentu bukanlah sesuatu yang mudah didifinisikan karena hal tersebut sangat berhubungan erat dengan pandangan konsumen. Secara umum di katakan bahwa kualitas adalah karakteristik produk atau jasa yang di tentukan oleh pemakai dan di peroleh melalui pengukuran proses serta melalui perbaikan yang berkelanjutan.

\section{Kualitas Pelayanan}

Kualitas merupakan sebuah suatu faktor penting yang diberikan perusahaan untuk para konsumennya. Menurut Mowen (2002) unsur yang paling penting dalam suatu produk atau jasa adalah kualitas yang tinggi yang dikendalikan oleh konsumen, karena itu perusahaan harus menilai persepsi konsumen atas kualitas. Sedangkan definisi pelayanan menurut Supranto (1997) pelayanan merupakan suatu kinerja penampilan, tidak berwujud dan cepat hilang, lebih dapat dirasakan dari pada dimilki, serta konsumen lebih dapat berpartisipasi aktif dalam proses mengkonsumsi jasa tersebut. Kualitas pelayanan adalah suatu instrumen dan strategi yang diberikan perusahaan untuk menarik minat konsumen untuk mengkonsumsi produk atau jasa yang diberikan, umumnya konsumen yang mengkonsumsi produk atau jasa, konsumen melihat dari kualitas yang diberikan serta pelayanannya, apabila kualitas pelayanan tersebut memuaskan konsumen akan timbul merasa keinginan yang mereka harapkan 
tercapai sehingga muncul perasan puas akan produk atau jasa tersebut. Kotler (2009) mengatakan bahwa kualitas jasa atau pelayanan harus dimulai dari kebutuhan pelanggan dan berakhir pada persepsi pelanggan, persepsi pelanggan terhadap kualitas jasa merupakan penilaian menyeluruh atas keunggulan suatu pelayanan.

Berdasarkan definisi diatas dapat disimpulkan bahwa kualitas pelayanan itu perlu dilakukan oleh perusahaan untuk menarik minat konsumen, dengan berminat diharapkan konsumen mengkonsumsi produk atau jasa yang ditawarkan, sehingga konsumen merasakan apa yang diharapkan bisa terpenuhi maka akan timbul perasaan puas pada hati konsumen. Perusahaan mempunyai strategi yang mencakup akan kualitas pelayanan itu sendiri, menurut Tjiptono (2007) strategi kualitas pelayanan yang dilakukan oleh perusahaan mencakup empat yaitu Atribut Pelayanan, Pendekatan untuk menyempurnakan kualitas jasa, dan sistem umpan balik.

Atribut Pelayanan. Suatu tata cara atau etika penyampaian pelayanan kepada para konsumen. Melakukan jasa pelayanan, hendaknya pelayanan tersebut dapat membuat konsumen menjadi merasa dihormati. Atribut pelayanan sangat dipengaruhi atas berbagai faktor antara lain: keterampilan hubungan antara pribadi, komunikasi, ilmu pengetahuan, sensitifitas, pemahaman dan berbagai perilaku eksternal. Pendekatan untuk menyempurnakan kualitas jasa. Kualitas jasa berpengaruh terhadap kualitas dan kuantitas konsumen. Agar kualitas jasa menjadi sempurna, maka perlu disertai beberapa faktor penunjang antara lain: faktor biaya, waktu penerapan program dan pengaruh pelayanan konsumen. Berdasarkan faktorfaktor tersebut maka kepuasan yang maksimal akan dapat dicapai. Sistem umpan balik yang salah satu cara untuk mengevaluasi dan memperbaiki kualitas konsumen adalah dengan menggunakan sistem umpan balik. Adanya sistem umpan balik maka posisi tingkat kualitas konsumen dapat diketahui, agar memperoleh hasil yang baik maka informasi umpan balik harus difokuskan pada beberapa hal yaitu mengukur dan memperbaiki kinerja perusahaan, memahami persepsi konsumen, dan menunjukan komitmen perusahaan pada kualitas produk pada para konsumen, serta mengembangkan sarana konsumen internal dengan tujuan agar para konsumen tahu mengenai apa yang harus mereka lakukan.

\section{Dimensi Kualitas Pelayanan}

Kualitas suatu produk baik berupa barang maupun jasa perlu ditentukan melalui dimensi-dimensinya. Beberapa pakar pemasaran seperti Parasuraman 
(1988) Zeithaml (1996) melakukan beberapa penelitian khusus terhadap beberapa jenis jasa dan mengidentifikasi faktor yang mempengaruhi kualitas jasa yang biasa disebut sebagai dimensi kualitas. Dalam perkembangannya, dimensi kualitas yang semula berjumlah sepuluh dirangkum menjadi lima dimensi pokok, sebagai berikut:

1. Tangible (bukti langsung), meliputi penampilan fisik, perlengkapan, pegawai, dan sarana komunikasi.

2. Reliability (keandalan), yaitu kemampuan memberikan pelayanan yang dijanjikan dengan segera, akurat, dan memuaskan.

3. Responsiveness (daya tanggap), yaitu keinginan para staf untuk membentuk para pelanggan dan memberikan pelayanan dengan tanggap.

4. Assurance (jaminan), mencakup pengetahuan, kemampuan, kesopanan, dan sifat dapat dipercaya yang dimiliki para staf bebas dari bahaya, resiko, atau keraguraguan.

5. Emphaty (empati), meliputi kemudahan dalam melakukan hubungan, komunikasi yang baik, perhatian pribadi, dan memahami kebutuhan pelanggan.

\section{Kepuasan Pelanggan atau Konsumen}

Kepuasan dalam melakukan suatu pembelian kadangkala terbentuk oleh rasa tidak puas dan puas. Meskipun demikian tidaklah gampang untuk menjadikan kepuasan pelanggan secara menyeluruh, oleh karena itu dapatlah dipahami bahwa ada kalangan pakar pemasaran berpendapat bahwa tidak realistik bila suatu perusahaan mengharapkan tidak ada pelanggan yang tidak puas. Dibawah ini dijelaskan beberapa pengertian kepuasan pelanggan oleh beberapa ahli:

a. Day (Dalam Tse dan Wilton, 1988)dan Fandy Tjiptono (1996): Kepuasan atau ketidakpuasan pelanggan adalah respon pelanggan terhadap evaluasi ketidaksesuaian atau dikonfirmasikan yang disesuaikan antara harapan sebelumnya (Norma kinerja lainnya) dan kinerja aktual produk yang dirasakan setelah pemakaiannya.

b. Kotler (1994) Kepuasan adalah tingkat perasaan seseorang setelah membandingkan kinerja atau hasil yang dirasakan dibandingkan dengan harapannya.

c. Engel, ef al (1990) dalam Fandy Tjiptono (1996) Kepuasan pelanggan merupakan evaluasipurnabeli dimana alternatif yang dipilih sekurangkurangnya memberikan hasil (Out Come) sama atau melampaui harapan pelanggan, sedangkan ketidakpuasan 
timbul apabila hasil yang diperoleh tidak memenuhi harapan pelanggan.

d. d. Willkie (1990) dalam Fandy Tjiptono (1996) Kepuasan pelanggan adalah suatu tanggapan emosional pada evaluasi terhadap pengalaman konsumsi suatu produk atau jasa. Dari definisi diatas terdapat kesamaan yaitu menyangkut komponen kepuasan atau harapan dari kinerja.
Umumnya harapan pelanggan merupakan perkiraan atau keyakinan pelanggan tentang apa yang akan diterimanya bila ia membeli atau mengkonsumsi suatu produk, sedang kinerja yang dirasakan adalah persepsi pelanggan terhadap apa yang ia terima setelah mengkonsumsi produk yang dibeli.

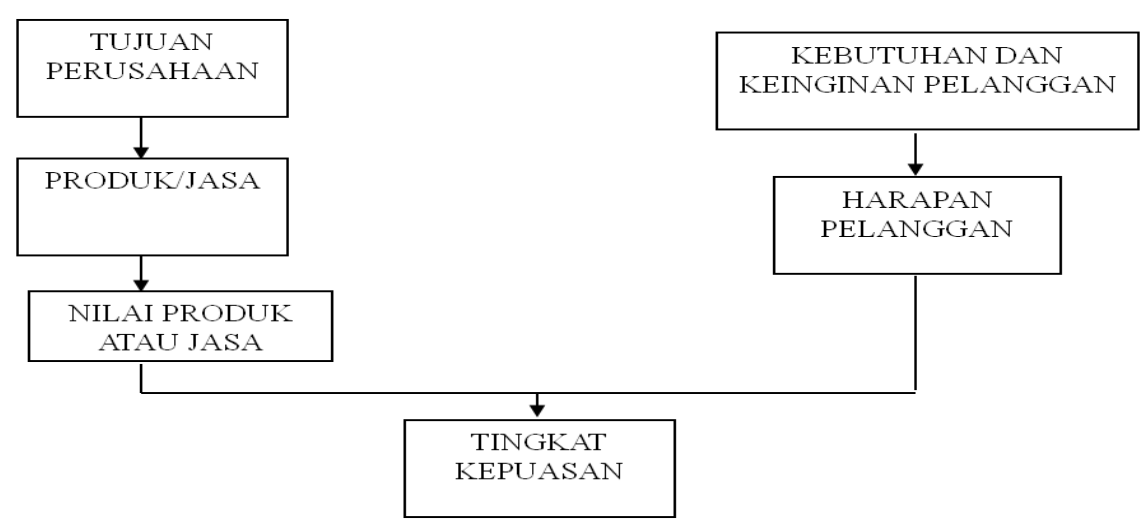

Sumber : Tjiptono (2004)

Gambar 1.Konsep Kepuasan Pelanggan

\section{Kerangka Pemikiran}

Penelitian ini bertujuan untuk mengetahui apakah ada pengaruh Bukti Langsung (Tangibles), Keandalan (Reliability), Daya Tanggap (Responsivenes), Jaminan (Assurance), Empati (Empathy) terhadap kepuasan konsumen. Dengan mengacu pada beberapa penelitian terdahulu maka kerangka teoritis dalam penelitian ini memadukan variable Bukti Langsung, Kehandalan, Daya Tanggap, Jaminan dan Empati yang mempengaruhi kepuasan konsumen. Kerangka penelitian ini digunakan untuk mempermudah jalan pemikiran terhadap masalah yang akan dibahas. Adapun kerangka konseptual yang dikembangkan dalam model ini adalah sebagai berikut: 


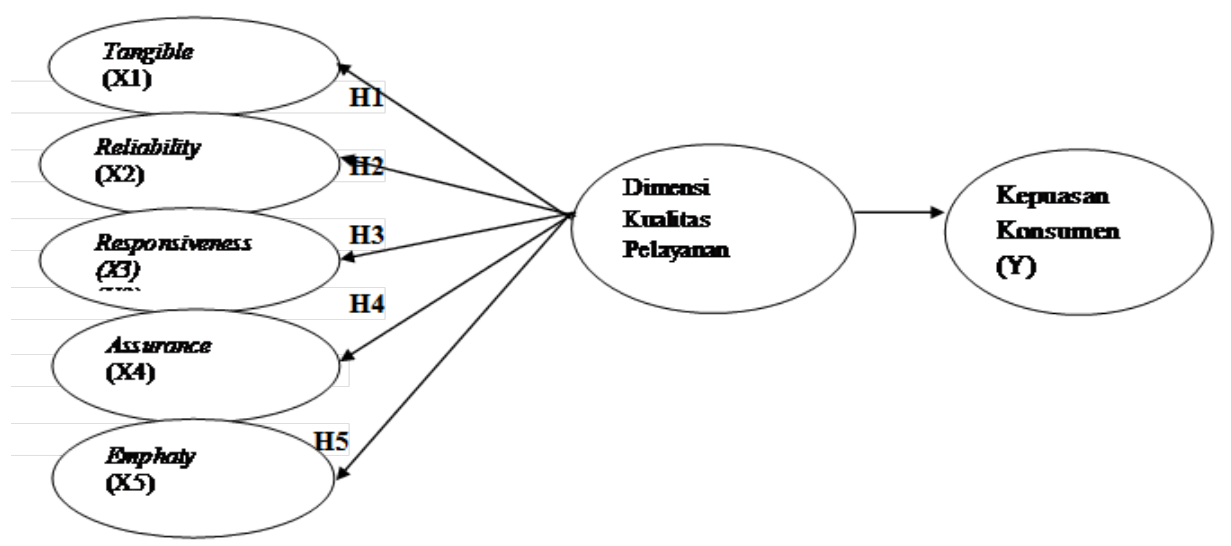

Berdasarkan Kerangka Pemikiran tersebut maka perumusan hipotesis dalam penelitian ini adalah sebagai berikut:

H1 :Terdapat pengaruh yang positif dan signifikan dari bukti langsung (Tangibles) terhadap kepuasan konsumen.

H2 : Terdapat pengaruh positif dan signifikan dari Kehandalan (Reliability) terhadap kepuasan konsumen.

H3 : Terdapat pengaruh positif dan signifikan dari daya tanggap (Responsivenes) terhadap kepuasan konsumen.

H4 : Terdapat pengaruh positif dan signifikan dari jaminan (Assurance) terhadap kepuasan konsumen.

H5 : Terdapat pengaruh positif dan signifikan dari perhatian (Empaty) terhadap kepuasan konsumen.

\section{METODE PENELITIAN}

Populasi dalam penelitian ini adalah pelanggan bus Transjogja yang diperoleh melalui teknik kuesioner tanggal 7-20 Mei 2014 yang diisi oleh pelanggan bus Transjogja. Sampel yang digunakan dalam penelitian ini adalah sebanyak 100 responden.

\section{HASIL DAN PEMBAHASAN}

Penyajian data mengenai identitas responden di sini, yaitu untuk memberikan gambaran tentang keadaan diri pada responden.Adapun gambaran tentang responden yang menjadi sampel dalam penelitian ini di klasifikasikan berdasarkan jenis kelamin, umur, tingkat pekerjaan. Berikut ini akan dibahas mengenai kondisi dari masingmasing klasifikasi demografis responden tersebut. Jumlah Responden Menurut Jenis Kelamin

\begin{tabular}{lll}
\hline Jenis & Jumlah & Persentase \\
Kelamin & Responden & \\
\hline Pria & 37 orang & $37 \%$ \\
Wanita & 63 orang & $63 \%$ \\
Total & 100 orang & $100 \%$ \\
\hline
\end{tabular}


Dengan variatifnya responden penumpang bus trans Jogja, maka akan memungkinkan responden juga bervariasiberdasarkan umur. Di sisi konsumen suatu produk, umur seringkali menjadipenentu atas tindakan atau keputusan atau perilaku berkaitan dengan suatu produkbarang atau jasa. Tabulasi umur responden dapat dilihat sebagai berikut :

Jumlah Responden Menurut Umur

\begin{tabular}{lll}
\hline$<20$ tahun & 35 orang & $35 \%$ \\
$20-30$ tahun & 43 orang & $43 \%$ \\
$31-50$ tahun & 22 orang & $22 \%$ \\
Total & $\mathbf{1 0 0}$ orang & $\mathbf{1 0 0} \%$ \\
\hline
\end{tabular}

Pekerjaan seringkali mempengaruhi perilaku seseorang dalam keputusannya.Selain itu pekerjaan pada umumnya juga mencerminkan satu bentuk perilaku pembelian tertentu terhadap suatu produk jasa. Tabulasi responden mengenai pekerjaan disajikan berikut ini:

\begin{tabular}{lll}
\hline Umur & $\begin{array}{l}\text { Jumlah } \\
\text { Responden }\end{array}$ & $\%$ \\
\hline
\end{tabular}

Jumlah Responden Menurut Pekerjaan

\begin{tabular}{lll}
\hline Pekerjaan & $\begin{array}{l}\text { Jumlah } \\
\text { Responden }\end{array}$ & $\begin{array}{l}\text { Persentase } \\
\mathbf{( \% )}\end{array}$ \\
\hline PNS & 10 orang & $10 \%$ \\
Pegawai Swasta & 14 orang & $14 \%$ \\
Pelajar/mahasiswa & 62 orang & $62 \%$ \\
Wiraswasta & 14 orang & $14 \%$ \\
Jumlah & 100 orang & $100 \%$ \\
\hline
\end{tabular}

\section{Analisis Hipotesis}

\begin{tabular}{|c|c|c|c|c|c|c|}
\hline HIPOTESIS & Hasil & Nilai Sign & Signifikasi & Kesimpulan & $\mathrm{R}^{2}$ & Hasil \\
\hline $\begin{array}{l}\mathrm{H} 1 \quad(+) \text { tangible } \\
\text { berpengaruh } \\
\text { terhadap } \\
\text { kepuasan } \\
\text { konsumen }\end{array}$ & 2,62 & 0,000 & Signifikan & Terbukti & 0,308 & $\begin{array}{l}\text { Tangible (bukti } \\
\text { fisik) } \\
\text { berpengaruh } \\
\text { signifikan } \\
\text { terhadap } \\
\text { Kepuasan } \\
\text { Konsumen }\end{array}$ \\
\hline $\begin{array}{l}\mathrm{H} 2(+) \text { reliability } \\
\text { berpengaruh } \\
\text { terhadap } \\
\text { kepuasan } \\
\text { konsumen }\end{array}$ & 0,170 & 0,000 & Signifikan & Terbukti & 0,305 & $\begin{array}{l}\text { Reliability } \\
\text { berpengaruh } \\
\text { signifikan } \\
\text { terhadap } \\
\text { Kepuasan }\end{array}$ \\
\hline
\end{tabular}




\begin{tabular}{|c|c|c|c|c|c|c|}
\hline HIPOTESIS & Hasil & Nilai Sign & Signifikasi & Kesimpulan & $\mathrm{R}^{2}$ & Hasil \\
\hline $\begin{array}{l}\mathrm{H} 3 \\
\text { responsiveness } \\
\text { berpengaruh } \\
\text { terhadap } \\
\text { kepuasan } \\
\text { konsumen }\end{array}$ & 0,070 & 0,000 & Signifikan & $\begin{array}{l}\text { Tidak } \\
\text { Terbukti }\end{array}$ & 0,194 & $\begin{array}{l}\text { Konsumen } \\
\text { Responsiveness } \\
\text { berpengaruh } \\
\text { terhadap } \\
\text { Kepuasan } \\
\text { Konsumen }\end{array}$ \\
\hline $\begin{array}{l}\mathrm{H} 4(+) \text { assurance } \\
\text { berpengaruh } \\
\text { terhadap } \\
\text { kepuasan } \\
\text { konsumen }\end{array}$ & 0,176 & 0,000 & Signifikan & Terbukti & 0,301 & $\begin{array}{l}\text { Assurance } \\
\text { berpengaruh } \\
\text { signifikan } \\
\text { terhadap } \\
\text { Kepuasan } \\
\text { Konsumen }\end{array}$ \\
\hline $\begin{array}{l}\text { H5 (+) empathy } \\
\text { berpengaruh } \\
\text { terhadap } \\
\text { kepuasan } \\
\text { konsumen }\end{array}$ & 0,058 & 0,000 & Signifikan & Terbukti & 0,259 & $\begin{array}{l}\text { Empathy } \\
\text { berpengaruh } \\
\text { signifikan } \\
\text { terhadap } \\
\text { Kepuasan } \\
\text { Konsumen }\end{array}$ \\
\hline
\end{tabular}

\section{Pembahasan}

Secara umum penelitian ini menunjukkan hasil yang cukup memuaskan. Hasil analisis deskriptif menunjukkan bahwa kualitas pelayanan yang diberikan oleh bus Trans Jogja secara umum sudah baik. Hal ini dapat ditunjukkan dari banyaknya tanggapan kepuasan yang tinggi dari respondenterhadap kondisi dari masingmasing variabel penelitian.Dari hasil tersebut selanjutnya diperoleh bahwa variabel kualitas pelayanan dalam kelima dimensinya memiliki pengaruh yang positif dan signifikan terhadap kepuasan konsumen. Hal ini dikarenakan bahwa dengan pemberian pelayanan yang berkualitas, maka hal tersebut akan menciptakan kepuasan dalam diri konsumen.

Hasil penelitian menunjukkan bahwa variabel tampilan fisik memilikipengaruh yang positif dan signifikan terhadap kepuasan. Hasil ini memberikan bukti empiris bahwa bukti fisik dari penyedia jasa yang ditunjukkan dengan fasilitas, interior dan sumber daya manusia sebagai pemberi pelayanan akanmenentukan kepuasan konsumen.

Hasil penelitian menunjukkan bahwa variabel kehandalan memilikipengaruh yang positif dan signifikan terhadap kepuasan konsumen. Hasil ini memberikan bukti empiris 
bahwa kehandalan dari penyedia jasa pelayanan yang ditunjukkan dengan kehandalan dalam bentuk kecepatan pelayanan, kemampuan pegawai, dan kehandalan pegawai dalam melayani konsumen akandipertimbangkan dalam membentuk kepuasan konsumen.

Hasil penelitian menunjukkan bahwa variabel daya tanggap memilikipengaruh yang positif dan signifikan terhadap kepuasan konsumen. Hasil ini memberikan bukti empiris bahwa daya tanggap dari penyedia jasa pelayanan yang ditunjukkan dengan kesediaan petugas dalam membantu, kesediaan staf dalam memberikan informasi, respon yang cepat dari karyawan, dan penyelesaian masalah dengan cepat akan memberikan pengaruh dalam terbentuknya kepuasan konsumen.

Hasil penelitian menunjukkan bahwa variabel jaminan memilikipengaruh yang positif dan signifikan terhadap kepuasan. Hasil ini memberikan bukti empiris bahwa jaminan dari penyedia jasa pelayanan akan memberikan peningkatan pada kepuasan konsumen. Hal ini ditunjukkan dengan kemampuan karyawan dalam melayani konsumen, karyawan yang mempunyai pengetahuan luas dan jaminan keamanan yang diberikan akan memberikan kesan yang lebih baik pada penyedia jasa bus Trans Jogja sehingga meningkatkan kepuasan konsumen.
Hasil penelitian menunjukkan bahwa variabel kepedulian memilikipengaruh yang positif dan signifikan terhadap kepuasan konsumen. Hasil ini memberikan bukti empiris bahwa adanya perhatian dari penyedia jasa pelayanan transpotasi umum bus Trans Jogja dalam bentuk perhatian yang sama, adanya kesesiaan petugas terhadap penumpang/konsumen yang membutuhkan bantuan, kemampuan komunikasi yang baik,kemampuan dalam memenuhi kebutuhan konsumen dan pemahaman setiapkondisi konsumen akan meningkatkan pandangan positif dari setiap tehadap pelayanan transportasi umum bus Trans Jogja. Hal ini selanjutnya akan memberikan kepuasan yang lebih tinggi.

\section{Saran Untuk Perusahaan}

Berdasarkan kesimpulan yang diperoleh dalam penelitian ini, maka diajukan saran-saran sebagai pelengkap terhadap kualitas pelayanan yang dapat diberikan oleh pengelola dan petugas bus Trans Jogja sebagai berikut :

1. Dalam kaitannya dengan jaminan, bus Trans Jogja perlu meningkatkan jaminan yang menjadi salah satu faktor penting yang berpengaruh terhadap kepuasan konsumen. Jaminan yang diberikan oleh bus Trans Jogja sudah cukup baik, perlu ditingkatkan dandipertahankan keramahan karyawan 
dan staf, karena sikap karyawan yang ramah akan membuat konsumen merasa senang dan nyaman dalam menerima pelayanan yang diberikan, dan perlu ditingkatkan lagi pengetahuan karyawan dengan cara memberikan pelatihan kepada karyawan sehingga konsumen merasa nyaman pada saat di berikan pelayanan.

2. Dalam kaitannya dengan bukti fisik, bus Trans Jogja perlu untuk melakukan perbaikan pada fisik bus dan halte, yaitu dapat dengan mengecat ulang body bus Trans jogja serta sentuhan desain budaya yang unik agar menambah kekhasan budaya kota Yogyakarta, dan memperbaiki AC yang rusak serta bagian fisik bus yang sudah rusak atau berkarat, merubah sebagian interior bus juga perlu dilakukan agar lebih bagus dan menarik. Selain itu interior dalam bus juga perlu dilakukan penataan ulang dan pengecekan setiap beberapa bulan sekali. Untuk fasilitas yang disediakan sudah bagus, tetapi masih perlu untuk ditingkatkan yaitu dengan memperbaiki fasilitas-fasilitas yang ada di bus maupun halte. Penampilan karyawan yang bersih dan rapi juga sangat mempengaruhi kepuasan konsumen, oleh karena itu karyawan dan staf harus mempertahankan penampilan mereka yang bersih dan rapi.

3. Dalam kaitannya dengan daya tanggap, daya tanggap yang diberikan oleh karyawan dan staf sudah cukup bagus, ini perlu untuk ditingkatkan, upaya inidapat dilakukan dengan cara petugas bus Transjogja harus cepat tanggapterhadap keinginan konsumen yaitu harus adanya karyawan yang selalu siap sedia di halte tunggu bus, sehingga ketika penumpang/konsumen membutuhkan bantuan bisa ditangani secepat mungkin, tanpa harus menunggu lama. Karyawan bus Transjogja harus lebih cepat tanggap terhadap keluhankonsumen, apabila ada konsumen yang membutuhkan bantuan atau ada yang mengeluhkan sesuatu yang berhubungan dengan kerusakan fasilitas atau pelayanan yang diberikan, maka karyawan bisa dengan cepat membantu dan menyelesaikan masalah. Pelayanan yang cepat juga mempengaruhi kepuasan konsumen karena biasanya konsumen tidak sabar apabila harus menunggu lama.

4. Dalam kaitannya dengan kehandalan, kehandalan karyawan dalam melayani konsumen dirasa sudah cukup baik, pengelola/pemerintah setempat harus mampu mempertahankan jika perlu lebih ditingkatkan lagi. Misalnya, petugas harus selalu siap sedia di halte atau di dalam bus agar apabila penumpang yang datang dapat segera dilayani. Prosedur pelayanan juga diharapkan tidak berbelitbelit dan juga dapat diupayakan penambahan fasilitas musik yang dapat 
dinikmati oleh para penumpang membuat para penumpang merasa nyaman. Meningkatkan ketrampilan dan pengetahuan karyawan dengan memberikan pelatihan, sehingga karyawan dapat dengan cepat dan tepat dalam melayani kosumen.

5. Dalam kaitannya dengan kepedulian, kepedulian seperti kesopanan dan keramahan yang diberikan olehpetugas bus Trans Jogja kepada konsumen sudah cukup baik, dan ini harus dipertahankan dan ditingkatkan dengan cara karyawan harus lebih peka terhadap keinginan dan kebutuhan konsumen, serta mengembangkan kemampuan berkomunikasi antara petugas dengan konsumen agar konsumen merasa nyaman dan puas menggunakan jasa bus Trans Jogja dan berkeinginan untuk kembali menggunakan jasa bus Trans Jogja. Kualitas pelayanan perlu diperhatikan oleh pihak bus Trans Jogja, karena semakin baik kualitas pelayanan di matakonsumen dan semakin tinggi tingkat kepuasan yang diperoleh konsumen maka akan semakin baik pula citra perusahaan/pengelola di lingkungan masyarakat.

\section{Penelitian yang akan datang}

Untuk penelitian kedepan disarankan dapat melakukan penelitian dengan aspek yang sama dengan menambahkan variabel yang menyangkut aspek tersebut untuk lebih mengetahui variabel-variabel lain yang mempengaruhi kepuasan konsumen, diluar variabel yang telah diteliti penulis. Seperti menambah variable independen lainnya selain bukti fisik (tangible), kehandalan (reliability), daya tanggap (responsiveness), jaminan (assurance), dan kepedulian (emphaty) yang tentunya dapat mempengaruhi variabel dependen kepuasan konsumen misalnya, efisiensi pelayanan dan efektifitas pelayanan, agar lebih melengkapi penelitian ini karena masih ada variabel-variabel independen lain di luar penelitian ini yang mungkin bisa mempengaruhi kepuasan konsumen.

\section{DAFTAR PUSTAKA}

Algifari, 2003, Statistik Induktif: untuk ekonomi dan bisnis, Edisi kedua, UPP AMP YKPN, Yogyakarta

Basu Swastha, 1984, Azas-azas Marketing, Edisi Ketiga, Liberty, Yogyakarta

Basu Swastha dan Irawan, 2001, Manajemen Pemasaran Modern, Liberty, Yogyakarta

Djunaidi, Moch, 2006, Analisis Kepuasan Pelangan dengan Pendekatan Fuzzy Service Quality dalam Upaya Peningkatan Kualitas Pelayanan, Jurnal Ilmiah Teknik Industri, Vol 4, No.3, April 2006, hal 139-146 
Engel, James F, and, Blackwell, Roger D, 1994, Perilaku Konsumen, Edisi Keenam, Jilid I, Binarupa, Jakarta

Fandy Tjiptono, 1995, Manajemen Jasa, Andi Offset, Yogyakarta

Ghozali, Imam, 2001, Aplikasi Analisis Multivariat dengan program SPSS, Badan Penerbit Universitas Diponegoro, Semarang

Ghozali, Imam, 2005, Aplikasi Analisis Multivariat dengan program SPSS, Badan Penerbit Universitas Diponegoro, Semarang

Handoko, Hani, 1997, Manajemen Personalia SDM, Edisi Ketiga, BPFE, Yogyakarta

Indriantoro,Supomo, 2002, Metodologi Penelitian bisnis untuk
Akuntansi dan Manajemen, Edisi Pertama, BPFE, Yogyakarta Kotler, Philip, 1994, Manajemen Pemasaran, Analisis Perencanaan, Implementasi dan Pengendalian, Edisi Kedelapan, Jilid I, Fakultas Ekonomi UI, Jakarta

Kotler, Philip, 1997, Manajemen Pemasaran, Analisis

Perencanaan,Implementasi dan Kontrol, Jilid I, PT Prehalindo, Jakarta

Nazir, Moh, 1999, Metode Penelitian, Cetakan Ketiga, Ghalia Indonesia, Jakarta

$$
\text { Parasuraman, Et, al., (1988), }
$$

Zeithmal and Bitner (1996), Konsep dan Teknik Pengukuran Kualitas Produk Jasa, Kajian Bisnis dan Manajemen, Vol 4,

No I, Hal 55-56 